Muslum Mursalov,

Ph.D., Azerbaijan State University of Economics, Azerbaijan

D ORCID ID, 0000-0003-4174-8093

\title{
BANKING REGULATIONS AND COUNTRY'S INNOVATIVE DEVELOPMENT: THE MEDIATING ROLE OF FINANCIAL DEVELOPMENT
}

Abstract. Promoting innovation requires efficient financial regulations ensuring well-functioning financial markets that play critical roles in reducing financing costs, allocating scarce resources, evaluating innovative projects, and managing risks. The author indicated that rigorous empirical studies that link financial regulation and innovation development are sparse. Thus, this study aims to provide some empirical evidence on linking government interventions, particularly by banking regulations and supervision, and a country's innovative growth from the perspective of the mediating role of financial development. Specifically, this paper demonstrates that the development of financial markets and financial institutions mediates the path between financial regulation and innovation development in Azerbaijan. The structural equation modelling technique using the statistical package PATH additionally to confirmatory factor analysis in STATISTICA was applied to analyze the data. Contrary to expectations, this study did not find a significant direct impact of changes in regulatory benchmarks related to total CAR and FX loans to total loans on Azerbaijan's rank in the Global Innovation Index and the volumes of high-technology exports. One of the more significant findings to emerge from this study is that the government regulatory and supervisory interventions in the banking sphere are changing the imprudent financial institutions' and markets' behaviour. Thereby it contributes to establishing a better developed and sound financial system in terms of their access, depth, and efficiency. Meanwhile, financial institutions' and markets' development contributes to the country's innovative development. This combination of findings provides some support for the conceptual premise that reduction or elimination of government power in the financial markets and institutions leads to exacerbating systemic risk and destabilization of the financial system that could not build extensive innovation capacities to foster growth.

Keywords: banking regulation and supervision, Global Innovation Index (GII), high-technology exports, financial institutions development, financial markets development.

Introduction. There is a growing body of literature that recognizes the importance of innovations in achieving robust, inclusive, and sustainable economic growth (Wang et al., 2013; Sineviciene et al., 2018; Lyeonov et al., 2019; Lazarov and Petreski, 2019). Recent developments in the field of innovations, numerous developed and developing countries have led to a renewed interest in the role of government interventions in the promotion of innovation growth. In line with Schumpeter (1911), a considerable amount of empirical research has confirmed the relationships between banking and financial markets development and fostering innovation (Ang, 2011; Hsu et al., 2014; Dovha and Boychenko, 201; Xin, 2019).

Development of both financial market and institution creates fertile grounds for expanding research and development $(R \& D, R+D)$ activities that companies or governments undertake creating new technology, products, services, or systems, and speeding up innovation growth in the country (King et al., 1993; Loayza and Ranciere, 2004). This claim originates from the fact that financial development allows reducing financing costs, allocating and reallocating scarce financial resources, evaluating and monitoring innovative projects, and managing risks. To date, many studies highlighted that government intervention, among other things through banking regulations and supervision, ensures cross-national differences in financial development (Lee and Lu, 2015; Barth et al., 2018; Islam and Khan,2019).

Following these arguments, the objective of the study is to provide some empirical evidence on linking

Cite as: Mursalov, M. (2020). Banking Regulations and Country's Innovative Development: the Mediating Role of Financial Development. Marketing and Management of Innovations, 4, 168-180. 
banking regulations and the country's innovative development from the perspective of the mediating role of financial development. The importance and originality of this study are that it demonstrates that financial institutions development and financial market development mediates the path between banking regulation and innovation development in Azerbaijan.

In attaining such an objective of the study, the research is divided into five sections. The first part is an introduction. The second part provides a theoretical background and develops the hypothesis of the study. The third part covers methodology and research methods, while the fourth part presents data analysis and results. Finally, the fifth part summarizes the findings and provides managerial implications and limitations of the study.

Literature Review. Besides the articles already mentioned, in particular the ones on addressing the financial background of the innovation activities, the paper is related to three distinct strains of the literature. First, it is linked to the investigations addressing the question about the financing of venture capital and innovation, in particular research literature focusing on the role of financial institutions and markets developments. A considerable amount of literature has been published on dependence innovation processes from finance (Black and Gilson, 1998; Kortum et al., 2000; Hellmann, 2002; Lerner et al., 2011; Manso, 2011; Tian and Wang, 2014; Karaoulanis, 2018; Vasylieva et al., 2018; Goncharenko, 2020). Kindleberger's (1996) work on linking financial market operations to radical innovations is complemented by Perez's (2002) study of the relation of financial capital behaviour and present information revolution as well as previous technological revolutions.

To better understand the mechanisms of financial intermediation and its effects, Bencivenga and Smith (1991) studied the role of banks in mediating financial resources to innovation industries and companies. They demonstrated that financial institutions determine the possible sources of the funding investment activities by affecting the volume of savings available. In another important study, Jovanovic and Greenwood (1990) found that financial structure development allows investors to channel financial resources into especially profitable, innovative vital sectors of the economy. Thus, financial markets development and financial institutions development affects the growth of investment productivity. A broader perspective was adopted by Nanda and Rhodes-Kropf (2013). They argue that not only financial developments but also the state of financial markets («hot») stimulate investors to finance cutting-edge experimentation and hence create and commercialize innovation results in international and domestic markets. In that study, they empirically confirm that funding innovation projects in the financial markets boom enhance value addition in national production and drastically increase registration of patents. In the recent cross-sectional study (Nanda and Rhodes-Kropf, 2017), it was shown that investors facing low financing costs and risk appeared to be favoured experimentation funding. In turn, they provide a positive interpretation of booms in activities on financial markets that facilitate rationale the inextricable chronological link between novel technologies propagation (e.g., waterways and canals (from 1771), telegraphs and railways (from 1829), telephones and electrical networks (from 1875), worldwide digital telecommunications and the Internet (from 1971), etc.) being caused by the increased financial market activity. Compared with previous studies, in which the rational respond of venture capitalists explained the link between financial market booms and innovations to attractive investment opportunities (Gompers et al., 2008), an overreaction of venture capitalists (Gompers and Lerner, 1998) or even herd behaviour for enhancing reputations of investment decisionmakers (Scharfstein and Stein, 1990).

Second, the problem under investigation is related to a strand of the literature that the banking regulatory framework establishes financial development in the country (Didenko and Dordevic, 2017; Naser, 2019). Through this focus area, the role of financial liberalization in financial development is one of the most studied researches. Thus, Leaven (1999) showed that the banking sector liberalization is stimulating financial development, especially by reducing imperfections in the functioning of national banking and improving the quality of financial services. While the first group of researches focusses on 
the positive link between financial deregulations and financial developments, Demirguc-Kunt and Detragiache (1998), Bailliu (2000), Andersen and Tarp (2003), Chinn and Ito (2006) regarded with the spillover effects of this linkage connected with imprudent bank behaviour, destabilizing outcomes, and risks. Thus, there is an increased number of adherents of the concept of moderated banking regulations and supervision that could lead to financial development through stabilization of its state (Boot et al., 2001; Barth et al., 2003; Li, 2007; Larsson and Söderberg, 2017).

A large volume of published studies reporting monetary policy institutions, through both dimensions central bank characteristics and the implemented monetary policy, have a particularly severe impact on financial development. Those studies mentioned inflation targeting through which financial stability and financial development could be enhanced (Boyd et al., 2001; Walsh, 2009; Piazzesi and Schneider, 2009; Woodford, 2012). However, other researchers looked at stock market development, have found the importance of macroeconomics policies in the context of ensuring the stability of the exchange rates, interest rates, the overall security situation (Kaehler et al., 2014).

Third, the paper is related to the scientific background on the direct and indirect effects through the financial development of regulatory and supervisory interventions in the banking sphere on innovation. To the best of our knowledge, there is a relatively small body of literature that is concerned with the importance of government involvement and regulations, especially in the banking sector, in the acceleration growth of innovations. Based on a large international panel of data, a recent comprehensive study by Ho et al. (2018) indicated that innovation grows in the country with a deepened financial system and enhanced political democracy. However, the conclusion is valid only if a country seeks to promote innovation with a bankconcentrated financial system. Otherwise, the enhancing effect of stock market deepening on innovation necessitates a lower level of political democracy.

It has also been suggested that legal rules, particularly in the sphere of strong shareholder protections and financial developments, enable external equity financing to be more affordable to risky, innovative investments that have been reluctant to finance debt (Brown et al., 2013). The earlier studies (Mclean et al., 2012) provided similar findings indicated the crucial role of investor protection in reducing financial constraints and stimulating investment. Ang (2011) points out that financial liberalization has an adverse consequence on innovation deepening. It was linked to the triggering of crises and imbalances taking place in the financial system, and reallocation of skilled, educated, talented workforce, equipped with knowledge of new emerging areas from the innovative sector to the financial system, consequently deceleration of technological deepening.

However, such studies remain narrow in focus dealing only with linking law and financial development with innovation activities. There are little known remain several aspects of banking regulation's effect through financial development on a country's innovation development. In the light of this research gap, this paper aims to provide an empirical assessment of the determinants of a country's innovation development by focusing on the roles of banking sector regulations and financial markets, and institutional developments. This issue deserves attention since in case the positive influence of banking regulation and financial development on the potential to improve a country's innovation performance, feasible and useful mechanisms are required to ensure innovation input and output growth.

Methodology and research methods. This part of the paper is devoted to developing and testing hypotheses by discussing two economic mechanisms through which banking regulation and supervision affect a country's innovation. Besides, the major economic theories and empirical findings allowed grounding the developed hypotheses. First, it was investigated whether adopted banking regulations and supervision are particularly beneficial to financial market development. Second, the paper examined whether financial market development is particularly beneficial to innovation inputs and outputs relevant for sustainable development and growth. In discussing these two economic mechanisms, the heterogeneous roles that financial markets and institutions developments play were emphasized. 
Thus, based on the empirical shreds of evidence mentioned earlier, researchers have formulated and tested the following hypotheses to state the link banking regulations and the country's innovative development from the perspective of the mediating role of financial development:

$\mathrm{H}_{1}$. Banking regulations and supervision have a significant positive impact on the country's innovative development (direct effect model).

$\mathrm{H}_{2 \mathrm{a}}$. Government interventions in the banking sector have a positive effect on the innovative performance of the country subject to the availability of developed financial institutions in terms of depth, access, and efficiency (the first mediating effect model).

$\mathrm{H}_{2 b}$. Government interventions in the banking sector, mediated by developed financial markets have a positive effect on the innovative performance of the country in terms of depth, access, and efficiency (the second mediating effect model).

$\mathrm{H}_{3}$. Financial development from the multidimensional perspective of financial institutions development and financial market development mediates the path between banking regulation and the country's innovation performance (parallel model of multiple mediating effects).

The use of structural simultaneous equations system is a well-established approach in psychology, political science, economics, and other social sciences (Kozmenko and Kuzmenko, 2011; Al Halbusi and Tehseen, 2018; Alsua et al., 2019; Abolfazl et al., 2019; Muneeb et al., 2019). Structural equation modelling (SEM) has several advantages over conventional multiple regressions. A major drawback associated with the use of individual regression equations in economic research is no capturing the complexities of the phenomenon. Structural equation modelling was chosen as a research method because it is a more useful tool to provide rounded, detailed illustrations of the complex systems and statistically test it. The study based on a hierarchical structural model. Herewith, SEPATH (structural equation modelling and path analysis) of STATISTICA was used to analyze the model's statistical verification analysis. In contrast to Akpoviroro et al. (2018), who used the moderator model, this study employed the structural equation modelling with mediating effect following Wang and Lam (2020) and Brychko et al. (2020).

The latent variables (also referred to as constructs) outlined the established conceptual model that represents a complex system of interactions that arise between banking regulation, financial development, and country's innovative development. These latent variables allowed describing the phenomena with an unknown inner structure and manifest (also referred to as observed) variables. Special attention during structural equation system modelling is also being paid to the problems of incorporating all important variables and indicators (both observer and latent). However, only those that are relevant, consistent with the true model, while keeping it as a simple structural model. Otherwise, a misspecified model with overly cumbersome hierarchical structures and lack of validity is not subject to evaluation and further analysis.

This part of the paper demonstrates the data, population, sample, variables, and their measurements. It stands to mention that innovation is a multidimensional phenomenon. Besides, it is difficult to gauge its inner mechanisms and elements because of poorly understanding. In most recent studies, innovations have been measured by a wide variety of indices, which comprises both separately input or output measures of innovation and in conjunction with each other. Thus, R\&D spending, the quality of publishing, patent performance, knowledge and technology outputs, and many others were used as an integral part of innovation indexes composition (Rejeb et al., 2008; Sohn et al., 2016; Fernandez Donoso, 2017; FredOjala et al., 2018).

In addition to independent researchers, different global organizations such as the Institute for Management Development (IMD), the World Economic Forum (WEF), the Global Innovation Index (GII), the Innovation Union Scoreboard engaged in the development of standard indicators for the quantification of innovations. These organizations developed the national innovative capacity metrics as a mine of information about countries' economic stability and growth through lasting sustainable innovation 
(Samoilikova, 2020). Despite their widespread use, such indices are subject to considerable criticism. While fully concurring with the limitations expressed by Fernandez Donoso (2017), innovation indexes are meaningless in terms of the sophistication of each invention (innovation) or the area where this innovation was invented.

By virtue of the lack of precision of such innovation metrics, confirmatory factor analysis (CFA) was implemented to identify the most persuaded attributes and features and test assumptions about the structure of the country's innovative development. In agreement with earlier studies, the country's innovation development was measured using the Global Innovation Index (GII) and High-technology exports (\% of manufactured exports). The Global Innovation Index (GII) (evolved in joining Cornell University, INSEAD, and World Intellectual Property Organization efforts) consisted of factors representing the institution, human capital and research, infrastructure, market and business sophistication, knowledge, technology, and creative outputs. Thus, compared with other indicators previously used in academic research, the strength of the Global Innovation Index derives from incorporating both input and output innovation sub-indices. Besides, high-technology exports as a percentage of manufactured exports are used as a catalyst for Azerbaijan's innovative development. Products with high research and development intensity necessarily entail the use of high technology and human capital. Therefore, high-technology exports also deployed both country's innovation input and output characteristics. In general, according to the confirmatory factor analysis, the proposed indicators allow $83 \%$ to determine the innovative development of the Republic of Azerbaijan.

Earlier studies such as Erdem (2010), Deskar-Skrbic et al. (2019), Dolgun and Gunduz (2018) measured banking regulation and supervision in the agreement using the ratio of total capital adequacy (Total CAR) and Foreign currency (FX) loans to the total loan portfolio. CFA was employed to validate the fitness of chosen proxies to represent the construct of banking regulation and supervision. In general, according to the confirmatory factor analysis, the proposed indicators (79\%) allow determining the banking regulations in the country.

The research database comprises the major measurement indicators describing the systemically important segments: banking regulation and the country's innovative development. These indicators are latent variables (constructs) that are socially constructed based upon observed indicators (measurement items) (Table 1).

Table 1. Constructs and measurement items of the conceptual model

\begin{tabular}{ccc}
\hline $\begin{array}{c}\text { Constructs } \\
\text { (latent variable) }\end{array}$ & $\begin{array}{c}\text { Items } \\
\text { (observed indicator) }\end{array}$ & Data sources \\
\hline $\begin{array}{c}\text { Banking regulation and } \\
\text { supervision }\end{array}$ & Total CAR & $\begin{array}{c}\text { Central Bank of the Republic of } \\
\text { Azerbaijan }\end{array}$ \\
\cline { 2 - 3 } Innovation development & FX loans to total loans, \% & $\begin{array}{c}\text { Global Innovation Index (Rank) } \\
\text { (GII) Reports }\end{array}$ \\
\cline { 2 - 3 } & $\begin{array}{c}\text { High-technology exports (\% of } \\
\text { manufactured exports) }\end{array}$ & IMF Data \\
\hline
\end{tabular}

Sources: developed by the authors.

Since some latent constructs included in the developed conceptual model could not be directly observed, a set of key observed items (measures) were used in each case. However, in this study, financial institutions development and financial markets development were measured by observed variables in the form of composite indicators. While evaluating a country's financial development, it is widely used the Financial Development Index (FDI) that represents different sides of the financial system characteristics. Based on the literature study, financial institutions development was measured by the $\mathrm{FI}$ sub-index that allows a comprehensive assessment of banks and other financial institutions as a matter 
of depth, access, and efficiency in intermediating savings to investment, operational efficiency, and profitability measures. While, financial markets development of the Republic of Azerbaijan was quantified by FM sub-index that evaluates the size and liquidity level of markets (depth), the ability of economic agents to access financial products and services (access), level of activity, and sustainable profitability of financial markets (efficiency).

Figure 1 represents the conceptual model that reflects links between all theoretical variables and hypotheses graphically.

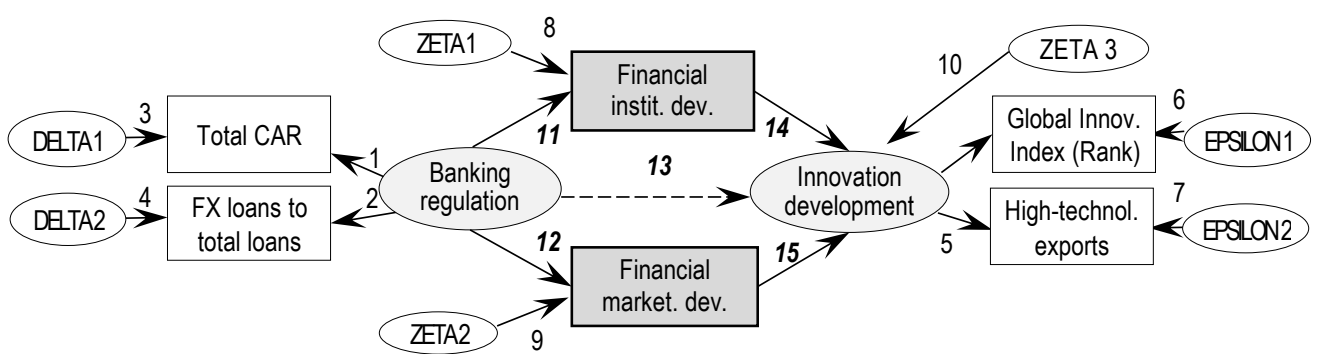

Figure 1. Graphical representation of the structural model of the study

Sources: developed by the authors.

Under the distinctive features of the latent variables, several statistical sources were used for the compilation of the research database. Herewith, the official site of the Central Bank of the Republic of Azerbaijan was a source of the data for the exogenous (independent) latent variable, i.e., banking regulation conducted by Azerbaijan. Besides, the Total CAR and FX loans to total loans were used as proxies. In turn, the official site of the IMF was the source of data for the first and second endogenous (dependent) observed variables, that are financial markets development and financial institutions development. In this case, financial institutions (FI) and financial markets (FM) development sub-indices were used as proxies. The Global Innovation Index (GII) reports and IMF Data were the sources for the third endogenous (dependent) latent variable. These are the country's innovative development, for which the Global Innovation Index (Rank) and high-technology exports (\% of manufactured exports) was used as proxies. The statistics on the observed variables selected for structural equation modelling were collected for the 10-year period, starting from 2009. The data is based on information obtained from the respective organizations of Azerbaijan.

Results. As it has previously stated, for testing the hypothetical research model, structural equation modelling was used. Since the conceptual, theoretical model consists of two latent constructs and six observed variables, confirmatory factor analysis for coefficients (factor loadings) estimations, confirmation of latent constructs validity, and fit were applied using the STATISTICA program.

Table 2 shows the output of standardized parameters and corresponding probability values for hypothesized links between latent contracts and observed variables (measurement model). Figure 2 depicts the structural model.

The developed hypotheses were confirmed or rejected through the interpretation of the obtained path coefficients. Empirical testing of the relationships between banking regulations, financial development, and the country's innovative growth shows that only a part of the relationships is statistically significant. Therefore, only several hypotheses have been confirmed. The conducted study did not confirm a statistically significant direct relationship between banking regulation and supervision and innovative development of the Republic of Azerbaijan. The summary of the results exhibited that null hypothesis $\mathrm{H}_{1}$ (direct effect model) has been rejected. Hence, it is conducted that any changes in regulatory benchmarks 
related to total CAR and FX loans to total loans have no significant direct impact on the rank of Azerbaijan in the Global Innovation Index as well as the volumes of high-technology exports.

Table 2. Results of SEM analysis

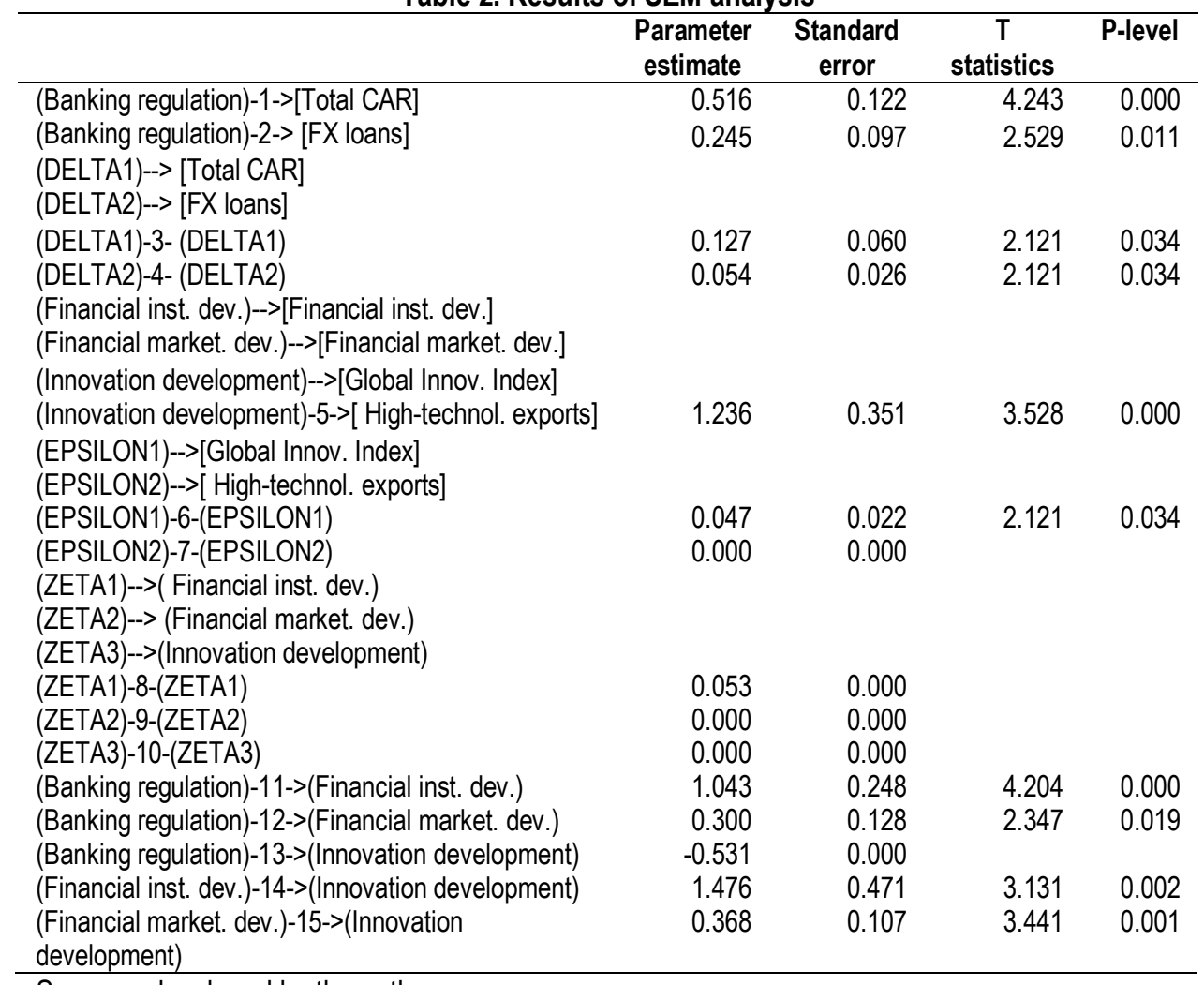

Sources: developed by the authors.

This study is primarily concerned with investigating the mediating role of financial development in the relationship between banking regulations and the country's innovative growth. Figure 2 illustrates the developed mediation model together with values on paths between latent constructs and observed variables (standardized regression coefficients) and numbers at latent constructs (factor loadings).

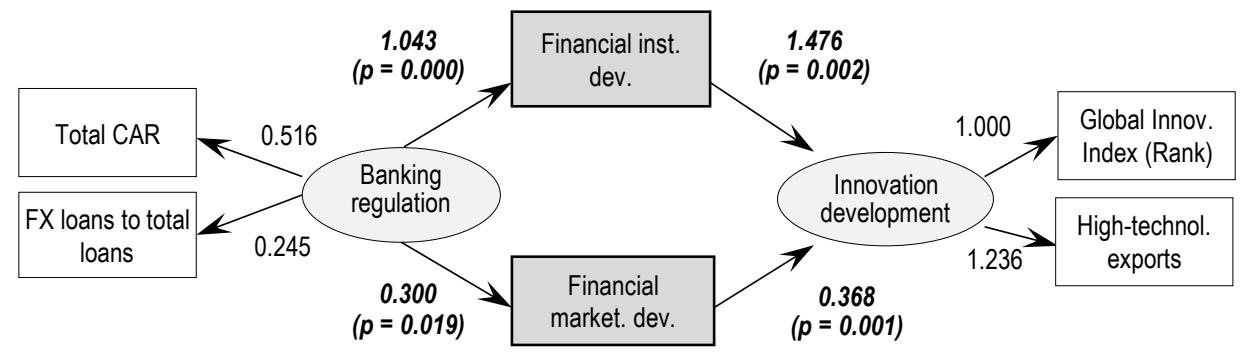

Figure 2. Outputs for the parallel model of multiple mediating effects

Sources: developed by the authors. 
In addition to path analysis of structural equations modelling employed to test the hypotheses by assessing the statistical significance of unmediated and mediated relationships, the Sobel test was used to investigate the statistical significance of mediation effects. Table 3 presents the calculations of the appropriate intermediate and some final results.

Table 3. Mediating effects (the Sobel test calculations)

\begin{tabular}{ccccc}
\hline Mediator & $\begin{array}{c}\text { Indirect effect } \\
(\mathrm{ab})\end{array}$ & SEab & Sobel test & $p$-value \\
\hline $\begin{array}{c}\text { Financial institutions } \\
\text { development }\left(\mathrm{H}_{2 \mathrm{a}}\right)\end{array}$ & 1.539 & 0.601 & 2.559 & 0.005 \\
\hline $\begin{array}{c}\text { Financial markets } \\
\text { development }\left(\mathrm{H}_{2 \mathrm{~b}}\right)\end{array}$ & 0.110 & 0.055 & 1.996 & 0.022 \\
\hline
\end{tabular}

Sources: developed by the authors.

Calculations presented in Table 3 revealed the significant impact of the financial institutions $\left(\mathrm{H}_{2 a}\right)$ and financial markets $\left(\mathrm{H}_{2 b}\right)$ development as mediating variables between banking regulations and supervision and innovative growth of the Republic of Azerbaijan. Thus, these positive relationships confirmed that hypotheses $\mathrm{H}_{2 a}$ and $\mathrm{H}_{2 b}$ were supported.

The following conclusions to emerge from the data stand out that banking regulations and supervision is changing the imprudent financial institutions' behaviour, thereby contributing to establishing a developed and sound financial system $(1.043, p=0.000)$. Meanwhile, financial institutions' development contributes to the country's innovative development (1.476, $p=0.002)$. In general, a one standard deviation increase in regulatory benchmarks related to banking regulations and supervision could expect the causal chain through the financial institutions' development to yield an increase in the innovative growth of 1.539 standard deviations $(p=0.005)$.

The second indirect effect model, where the development of the financial markets served as a mediator, indicated that banking regulations and supervision lead to obviously better developed financial markets in terms of their access, depth, and efficiency $(0.300, p=0.019)$. However, the impact of banking regulations and supervision on financial markets development is lesser as compared to financial institutions' development. Nonetheless, financial markets development plays a significant role in the innovation growth of Azerbaijan $(0.368, p=0.001)$. Overall, a one standard deviation increase in regulatory benchmarks related to banking regulations and supervision could expect the causal chain through the development of the financial markets to yield an increase in the innovative growth of 0.110 standard deviations $(p=0.022)$.

The parallel model of multiple mediating effects reflecting total mediation effect could be calculated as a sum of mediated effects. According to the obtained results, the total mediation effect is about 1.649. Thus, hypothesis $\mathrm{H}_{3}$ was supported. These results suggest that a one standard deviation increase in the regulatory benchmarks related to banking regulations and supervision could expect the causal chain through the development of the financial institutions and markets to yield an increase in the innovative growth of 1.649 standard deviations.

Furthermore, taking into account that the unmediated effect is not significantly different from zero when controlling for the mediators, the obtained empirical results have demonstrated a full mediation. It assumes that financial institutions and markets development are the sole mediators of the effect of banking regulations and supervision on Azerbaijan's innovative development. Specifically, the unmediated (direct) effect of banking regulations and supervision on Azerbaijan's innovative development was significant, only in case the mediators are absent. When the mediators (financial institutions and markets development) 
were incorporated in the developed conceptual model, this unmediated effect becomes insignificant, while the mediating effect is significant.

The decision to reject or support hypotheses about mediation effects was made based on the Sobel method (Sobel, 1982a,b) known as Z-test. One of the Sobel test's significant advantages is that it is not computationally intensive. Thus, it is the simplest to use, and it works pretty well compared to other alternative tests. However, there are certain drawbacks associated with the use of the Sobel method. One of these is that it does not allow confidence intervals for mediated effects compared to the bootstrap method. Based on the Sobel test's calculated values (Z-values), using a normal probability table p-value could be found. Relying upon normal distribution theory to reach the 0.05 significance level, the Sobel test Z-value calculated should not exceed the value defined as 1.96. Since estimated z-test values for both mediation effects (Table 3 ) exceeds the recommended empirical critical $Z$ value. Therefore, hypotheses about the mediated role of financial institutions and markets development were supported.

In this study, several goodness-of-fit indices are used. That was made due to the arguments mentioned in previous studies (Balakrishnan et al., 2016; Ngo and Pavelkova, 2017; Ahmed et al., 2017) suggesting to employ more than one goodness-of-fit index to determine the model fit statistics of the proposed conceptual model. Although there is a great number of absolute, relative, parsimonious fit indexes, and non-centrality based goodness-of-fit indices, there is no single opinion on one or set of «best» index that should be utilized to evaluate the adequacy of the goodness of fit. Table 4 disclosed the decision on goodness-of-fit indices, the results of fit measures for the structural model and their threshold values.

Along with the majority of research studies, this paper is used as the most common absolute goodness-of-fit test - the relative Chi-Square Statistic (X2/df) that allows defining whether the model is plausible in the population. The calculated value demonstrates the acceptable fit, considering the sensitivity of this indicator to sample size. However, even in this case, the relative Chi-Square Statistic $(\mathrm{X} 2 / \mathrm{df})$ should not be used as a sole indicator to assess the adequacy of constructed regression equations in the description of the structural relationships of the complex system.

Specifically, the comparative fit index $(\mathrm{CFI})=0,026$, the normed fixed index $(\mathrm{NFI})=0,935$, the TuckerLewis coefficient index $(T L I)=0,030$, the goodness of fit index $(G F I)=0,979$, the root mean square error of approximation (RMSEA) $=0,951$ were calculated for additional analysis of goodness-of-fit. According to the recommended threshold values, these indices show a good fit for the conceptual research model.

Table 4. Structural model fit statistics

\begin{tabular}{ccc}
\hline Fit index & Criterion (threshold values) & Structural model values \\
\hline X2 & $\leq 3$ & 1.169 \\
p-level & $>0.05$ & 0.099 \\
CFI & $\leq 0.05$ & 0.026 \\
NFI & $\geq 0.9$ & 0.935 \\
TLI & $<0.5$ & 0.030 \\
GFI & $\geq 0.95$ & 0.979 \\
RMSEA & $\geq 0.95$ & 0.951 \\
\hline
\end{tabular}

Sources: developed by the authors.

Therefore, the findings allow concluding that the proposed structural model is statistically significant and shows a good fit with the empirical data. That indicates that the proposed conceptual model could be used to explain the link between banking regulations and supervision and the country's innovative development considering the mediating effect of financial institutions development and financial markets development. 
Conclusions. The present study was designed to determine the nature of the relationship between banking regulations, supervision and innovative development of the Republic of Azerbaijan from the perspective of the mediating role of financial development. This paper has filled the gap by contributing to the scientific background by closely examining the mediating effect of financial development of institutions and markets separately and together. Empirical data collection having a sufficient number of items with careful modification and improvement has been adapted for this research. The obtained findings make several contributions to the current scientific background and lay the groundwork for future research.

By providing an empirical body of evidence about the mediated effect, this study shows that there are no other processes, distinct from whatever financial development transmits, through which banking regulations and supervision would yield an increase in country's innovative development indicators (i.e., the rank in the Global Innovation Index and the volume of high-technology exports).

This research supports the conclusion that there is no unmediated impact of government interventions in the form of banking regulations and supervision on innovations. Simultaneously, the study indicates that the regulatory and supervisory interventions in the banking sphere reduce imperfections in the functioning banking system, hence, developing financial institutions and markets, assuming acceleration growth of innovations. In the mediation effect models, gained full mediation indicates that the process by which banking regulations and supervision influences innovative development has been thoroughly explained. Herewith, it suggests that it is unnecessary to search for further mediated effects.

These findings have significant implications for the understanding that well-functioning and developed financial institutions and markets could play a vital role in the process of channelling banking regulations and supervision to a country's innovative development. The present study has found that generally, government involvement in the financial markets and institutions has vast positive implications and suppresses the financial sector's deregulation soon.

Future investigations should be carried out in a more in-depth analysis of financial institutions and markets developments in the context of the obtained research results. It could be possible if the development of the financial institution and markets be incorporated into a study as latent constructs and include observed indicators that characterize their depth, access, and efficiency. For this purpose, more comprehensive data for a bigger period of analysis should be taken.

\section{References}

Ahmed, R. R., Vveinhardt, J., Streimikienè, D., Ashraf, M., \& Channar, Z. A. (2017). Modified SERVQUAL model and effects of customer attitude and technology on customer satisfaction in banking industry: mediation, moderation and conditional process analysis. Journal of Business Economics and Management, 18(5), 974-1004. [Google Scholar] [CrossRef]

Akhondzadeh, A. (2019). Analysis of the Factors Affecting the Implementation of Virtual R\&D in Iranian Tile and Ceramic Companies Using Structural Equation Modeling Approach. SocioEconomic Challenges, 3(4), 86-96. [Google Scholar] [CrossRef]

Akpoviroro, K. S., Akanmu, P. M., Olalekan, A., \& Alhaji, S. A. (2018). Moderating Influence of Organizational Reward System on Employee's Performance. SocioEconomic Challenges, 2(4), 114-122. [Google Scholar] [CrossRef]

Al Halbusi, H., \& Tehseen, S. (2018). The Effect of Electronic Word-Of-Mouth (EWOM) On Brand Im-age and Purchase Intention: A Conceptual Paper. SocioEconomic Challenges, 3(2), 83-94. [Google Scholar] [CrossRef]

Alsua, C. J., Palacios-Fenech, J., \& Ramirez, J. (2019). Social Preferences, Goal Orientation and Team Performance. Business Ethics and Leadership, 3(1), 6-17. [Google Scholar] [CrossRef]

Andersen, T. B., \& Tarp, F. (2003). Financial liberalization, financial development and economic growth in LDCs. Journal of International Development: The Journal of the Development Studies Association, 15(2), 189-209. [Google Scholar] [CrossRef]

Ang, J. B. (2011). Financial development, liberalization and technological deepening. European Economic Review, 55(5), 688701. [Google Scholar] [CrossRef]

Bailliu, J. (2000). Private capital flows, financial development, and economic growth in developing countries (No. 2000-15). Bank of Canada. [Google Scholar]

Balakrishnan, N., Barmalzan, G., \& Haidari, A. (2016). Multivariate stochastic comparisons of multivariate mix ture models and their applications. Journal of Multivariate Analysis, 145, 37-43. [Google Scholar] [CrossRef]

Baranovskyi, O. I. (2020). Regulation of functional and structural transformational processes in the financial sector. Financial and credit activity: problems of theory and practice, 1(32), 292-306. [Google Scholar] [CrossRef] 


\section{M., Mursalov. Banking Regulations and Country's Innovative Development: the Mediating Role of Financial Development}

Baranovskyi, O. I. (2018). Quality of the transformational processes in the financial sector of the national economy: vectors of the measurement. Financial and credit activity: problems of theory and practice, 3(26), 350-367. [Google Scholar] [CrossRef

Barth, J. R., \& Caprio Jr, G. (2018). Regulation and supervision in financial development. In Handbook of Finance and Development. Edward Elgar Publishing, 393-418. [Google Scholar] [CrossRef]

Barth, J. R., Nolle, D. E., Phumiwasana, T., \& Yago, G. (2003). A cross-country analysis of the bank supervisory framework and bank performance. Financial Markets, Institutions \& Instruments, 12(2), 67-120. [Google Scholar] [CrossRef]

Bencivenga, V. R., \& Smith, B. D. (1991). Financial intermediation and endogenous growth. The review of economic studies, 58(2), 195-209. [Google Scholar] [CrossRef]

Black, B. S., \& Gilson, R. J. (1998). Venture capital and the structure of capital markets: banks versus stock markets. Journal of financial economics, 47(3), 243-277. [Google Scholar] [CrossRef]

Boiarko, I. M. (2016). Praxeological and situational approaches in the formation of strategic accounting. Financial and credit activities: problems of theory and practice, 2(21), 80-90. [CrossRef]

Boot, A. W., Dezelan, S., \& Milbourn, T. T. (2001). Regulation and the evolution of the financial services industry. In Challenges for central banking (pp. 39-58). Springer, Boston, MA. [Google Scholar] [CrossRef]

Boyd, J. H., Levine, R., \& Smith, B. D. (2001). The impact of inflation on financial sector performance. Journal of monetary Economics, 47(2), 221-248. [Google Scholar] [CrossRef]

Brown, J. R., Martinsson, G., \& Petersen, B. C. (2013). Law, stock markets, and innovation. The Journal of Finance, 68(4), 1517-1549. [Google Scholar] [CrossRef]

Brychko, M., Bilan, Y., Lyeonov, S., \& Mentel, G. (2020). Trust crisis in the financial sector and macroeconomic stability: a structural equation modelling approach. Economic Research-Ekonomska Istraživanja, 1-28. [Google Scholar] [CrossRef]

Central Bank of the Republic of Azerbaijan. (2019). Statistical bulletin 12/31/2008 to 12/31/2019. Retrieved from [Link]

Chinn, M. D., \& Ito, H. (2006). What matters for financial development? Capital controls, institutions, and interactions. Journal of development economics, 81(1), 163-192. [Google Scholar] [CrossRef]

Demirguc-Kunt, A., \& Detragiache, E. (1998). The determinants of banking crises in developing and developed countries. Staff Papers, 45(1), 81-109. [Google Scholar] [CrossRef]

Deskar-Skrbic, M., Kotarski, K., \& Brkic, L. (2019). Banking Regulation in Croatia: qualitative and quantitative assessment. In Policy-Making at the European Periphery (pp. 187-205). Palgrave Macmillan, Cham. [Google Scholar] [CrossRef]

Didenko, O., \& Dordevic, S. (2017). The optimization of banking regulation intensity from the perspective of finan-cial stability in banking sector: an empirical analysis. Financial markets, institutions and risks, 1(1), 43-53. [Google Scholar] [CrossRef]

Dolgun, M. H., \& Gunduz, L. (2018). Turkish Banking Industry: A CAMELS Analysis. Turkish Economy, 193-211. [Google Scholar] [CrossRef]

Donoso, J. F. (2017). A simple index of innovation with complexity. Journal of informetrics, 11(1), 1-17. [Google Scholar] CrossRef

Dovha, N., \& Boychenko, V. (2017). Can banking innovations lead to new financial crisis: case of Central and Eastern Europe. Financial Markets, Institutions and Risks, 1(2), 80-86. [Google Scholar] [CrossRef]

Erdem, M. S. (2010). Turkish banking system in the face of the global crisis. International Journal of Islamic and Middle Eastern Finance and Management. [Google Scholar] [CrossRef]

Fred-Ojala, A., Sidhu, I., Johnsson, C., \& Suoranta, M. (2018). The Berkeley Innovation Index: A Quantitative Approach to Measure, Track and Forecast Innovation Capability Within Individuals and Organizations. In International Conference on Mobile and Wireless Technology (pp. 311-320). Springer, Singapore. [Google Scholar] [CrossRef]

Gompers, P., \& Lerner, J. (1998). Venture capital distributions: Short-run and long-run reactions. The Journal of Finance, 53(6), 2161-2183. [Google Scholar] [CrossRef]

Gompers, P., Kovner, A., Lerner, J., \& Scharfstein, D. (2008). Venture capital investment cycles: The impact of public markets. Journal of financial economics, 87(1), 1-23. [Google Scholar] [CrossRef]

Goncharenko, T. (2020). From Business Modelling to the Leadership and Innovation in Business: Bibliometric Analysis (Banking as a Case). Business Ethics and Leadership, 4(1), 113-125. [Google Scholar] [CrossRef]

Hellmann, T. (2002). A theory of strategic venture investing. Journal of financial economics, 64(2), 285-314. [Google Scholar] [CrossRef]

Ho, C. Y., Huang, S., Shi, H., \& Wu, J. (2018). Financial deepening and innovation: The role of political institutions. World Development, 109, 1-13. [Google Scholar] [CrossRef]

Hrytsenko, L. L., Roienko, V., \& Boiarko, I. M. (2018). Institutional background of the role of state in investment processes activation. Financial and credit activities: problems of theory and practice, 1(24), 338-344. [CrossRef]

Hsu, P. H., Tian, X., \& Xu, Y. (2014). Financial development and innovation: Cross-country evidence. Journal of Financial Economics, 112(1), 116-135. [Google Scholar] [CrossRef]

Islam, S. T., \& Khan, M. Y. H. (2019). Evaluating the changes in the European Banking Regulation - MiFID and its possible effects on the Global Economy: A Theoretical Study. Financial Markets, Institutions and Risks, 3(4), 24-31. [Google Scholar] [CrossRef]

Jovanovic, B., \& Greenwood, J. (1990). Financial development, growth, and the distribution of income. Journal of Political Economy, 98(5), 1076-1107. [Google Scholar] [CrossRef] 


\section{M., Mursalov. Banking Regulations and Country's Innovative Development: the Mediating Role of Financial Development}

Kaehler, J., Weber, C. S., \& Aref, H. S. D. (2014). The Iraqi Stock Market: Development and Determinants. Review of Middle East Economics and Finance, 10(2), 151-175. [Google Scholar] [CrossRef]

Karaoulanis, A. (2018). Strategic Transformation and Innovation towards Blue Ocean Creation in a Changing Corporate Reality. Business Ethics and Leadership, 2(2), 49-55. [Google Scholar] [CrossRef]

King, R. G., \& Levine, R. (1993). Finance, entrepreneurship and growth. Journal of Monetary economics, 32(3), 513-542. [Google Scholar] [CrossRef]

Kozmenko, O. V., \& Kuzmenko, O. V. (2011). Using structural modeling for studying the indicators of insurance and banking services markets. Actual problems of economics, (119), 284-292. [Google Scholar]

Kuznyetsova, A. Y., \& Klishchuk, O. V. (2017). Theoretical conception of price stability targeting arrangement: investigation of basic principles of implementation monetary regime. Financial and credit activity: problems of theory and practice, 2(23), 388-396. [Google Scholar] [CrossRef]

Laeven, L. (1999). Does financial liberalization relax financing constraints on firms?. The World Bank. [Google Scholar]

Larsson, M., \& Söderberg, G. (2017). Banking Development, the Global Financial Crisis and the Basel Regulations: 1995-2015. Finance and the Welfare State, 123-133. [Google Scholar] [CrossRef]

Lazarov, D., \& Petreski, G. (2019). The role of innovations in fostering economic growth: an empirical analysis for selected CEE countries. International Journal of Business and Globalisation, 22(4), 716-728. [Google Scholar] [CrossRef]

Lee, K., \& Lu, W. (2015). Do bank regulation and supervision matter? Journal of Financial Economic Policy, 7(3), 275-288. [Google Scholar] [CrossRef]

Lerner, J. (2000). Assessing the contribution of venture capital. the RAND Journal of Economics, 31(4), 674-692. [Google Scholar] [CrossRef]

Lerner, J., Sorensen, M., \& Strömberg, P. (2011). Private equity and long-run investment: The case of innovation. The Journal of Finance, 66(2), 445-477. [Google Scholar] [CrossRef]

Li, T. (2007). Banking Regulation around the World: Patterns, Determinants, and Impact. Journal of Emerging Market Finance, 6(1), 61-122. [Google Scholar] [CrossRef]

Loayza, N., \& Ranciere, R. (2004). Financial Development, Financial Fragility, and Growth. Policy Research Working Papers. [Google Scholar] [CrossRef]

Lyeonov, S., Pimonenko, T., Bilan, Y., Streimikienè, D., \& Mentel, G. (2019). Assessment of Green Investments' Impact on Sustainable Development: Linking Gross Domestic Product Per Capita, Greenhouse Gas Emissions and Renewable Energy Energies, 12(20), 3891. [Google Scholar] [CrossRef]

Manso, G. (2011). Motivating innovation. The Journal of Finance, 66(5), 1823-1860. [Google Scholar] [CrossRef]

McLean, R. D., Zhang, T., \& Zhao, M. (2012). Why does the law matter? Investor protection and its effects on investment, finance, and growth. The Journal of Finance, 67(1), 313-350. [Google Scholar] [CrossRef]

Muneeb, F. M., Chughtai, M. S., Anjum, U., \& Ma, J. (2019). Fostering Employee's Service Quality and Customer Satisfaction: Evidence from Emerging Pakistan. Business Ethics and Leadership, 3(3), 47-67. [Google Scholar] [CrossRef]

Nanda, R., \& Rhodes-Kropf, M. (2013). Investment cycles and startup innovation. Journal of Financial Economics, 110(2), 403418. [Google Scholar] [CrossRef]

Nanda, R., \& Rhodes-Kropf, M. (2017). Financing risk and innovation. Management Science, 63(4), 901-918. [Google Scholar] [CrossRef]

Naser, N. (2019). A Comprehensive Analysis of European Banking Soundness - Theoretical Study. Financial Markets Institutions and Risks, 3(2), 17-43. [Google Scholar] [CrossRef]

Ngo, V. M., \& Pavelkova, D. (2017). Moderating and mediating effects of switching costs on the relationship between service value, customer satisfaction and customer loyalty: investigation of retail banking in Vietnam. Journal of International Studies, 10(1), 9-33. [Google Scholar] [CrossRef]

Piazzesi, M., \& Schneider, M. (2009). Inflation and the price of real assets (Vol. 423). Federal Reserve Bank of Minneapolis, Research Department. [Google Scholar] [CrossRef]

Rejeb, H. B., Morel-Guimarães, L., \& Boly, V. (2008). Measuring innovation best practices: Improvement of an innovation index integrating threshold and synergy effects. Technovation, 28(12), 838-854. [Google Scholar] [CrossRef]

Rekunenko, I. I., Hrytsenko, L. L., Boiarko, I. M., \& Kostyrko, R. A. (2019). Financial debt market in the system of indicators of development of the economy of the country. Financial and credit activities: problems of theory and practice, 2(29), 430-439.

Samoilikova, A. (2020). Financial Policy of Innovation Development Providing: The Impact Formalization. Financial Markets, Institutions and Risks, 4(2), 5-15. [Google Scholar] [CrossRef]

Scharfstein, D. S., \& Stein, J. C. (1990). Herd behavior and investment. The American economic review, 465-479. [Google Scholar]

Schumpeter, J. (1911). The theory of economic development. Cambridge, MA: Harvard University Press. [Google Scholar]

Sineviciene, L., Shkarupa, O., \& Sysoyeva, L. (2018). Socio-economic and Political Channels for Promoting Innovation as a Basis for Increasing the Economic Security of the State: Comparison of Ukraine and the Countries of the European Union. SocioEconomic Challenges, 2(2), 81-93. [Google Scholar] [CrossRef]

Sobel, M. E. (1982a). Asymptotic confidence intervals for indirect effects in structural equation models. In Leinhardt, S. (Ed.), Sociological methodology, 13, 290-312. American Sociological Association. [Google Scholar] [CrossRef] 


\section{M., Mursalov. Banking Regulations and Country's Innovative Development: the Mediating Role of Financial Development}

Sobel, M. E. (1982b). Some new results on indirect effects and their standard errors in covariance structure models. Sociological Methodology, 16, 159-186. [Google Scholar] [CrossRef]

Sohn, S. Y., Kim, D. H., \& Jeon, S. Y. (2016). Re-evaluation of global innovation index based on a structural equation model. Technology Analysis \& Strategic Management, 28(4), 492-505. [Google Scholar] [CrossRef]

Tian, X., \& Wang, T. Y. (2014). Tolerance for failure and corporate innovation. The Review of Financial Studies, 27(1), $211-255$. [Google Scholar] [CrossRef]

Umadia Sr. K., \& Kasztelnik, K. (2020). The Financial Innovative Business Strategies of Small to Medium Scale Enterprises in Developing Country and Influence for the Global Economy Performance. SocioEconomic Challenges, 4(3), 20-32. [Google Scholar] [CrossRef]

Vasylieva, T., Lyeonov, S., Lyulyov, O., \& Kyrychenko, K. (2018). Macroeconomic Stability and Its Impact on the Economic Growth of the Country. Montenegrin Journal of Economics, 14(1), 159-170. [Google Scholar] [CrossRef]

Vovchak, O. D., Senyshch, P. M., \& Melnyk, T. V. (2019). «Purging» of the banking system: impacton the key performance indicators of banks. Financial and credit activity: problems of theory and practice, 1(28), 16-25. [Google Scholar] [CrossRef]

Walsh, C. E. (2009). Inflation Targeting: What Have We Learned? International Finance, 12(2), 195-233. [Google Scholar] [CrossRef]

Wang, D. H. M., Yu, T. H. K., \& Liu, H. Q. (2013). Heterogeneous effect of high-tech industrial R\&D spending on economic growth. Journal of Business Research, 66(10), 1990-1993. [Google Scholar] [CrossRef]

Wang, F., Lo, J., \& Lam, M. (2020). Mediating Effects of Stakeholders and Supervision on Corporate Social Responsibility. Business Ethics and Leadership, 4(1), 43-56. [Google Scholar] [CrossRef]

Xin, Y. (2019). Spatial effects of financial scale and financial structure on technological innovation of enterprises. Proceedings of the 2019 4th International Conference on Financial Innovation and Economic Development (ICFIED 2019). [Google Scholar] [CrossRef]

\section{Мурсалов Муслім Мурсал оглі}

Ph.D., Азербайджанський державний економічний університет, Азербайджан

Банківське регулювання та інноваційний розвиток держави: посередницька роль фінансового розвитку

Ефективне фінансове регулювання забезпечує стрімкий розвиток інновацій та сприяє належному функціонуванню фінансових ринків. При цьому ефективний механізм функціонування ффінансових ринків відіграє важливу роль при зменшенны витрат на фінансування, розподілі обмежених ресурсів, оцінці інноваційних проєктів та управлінні ризиками. У статті наголошено на обмеженості емпіричних досліджень щодо питань фінансового регулювання та інноваційного розвитку. Метою статті є емпіричне підтвердження взаємозв'язку між державним втручанням (зокрема за допомогою банківських норм та нагляду) та інноваційним зростанням країни з точки зору посередницької ролі фрінансового розвитку. У роботі зазначено, що розвиток фрінансових ринків та установ опосередковує шлях між фрінансовим регулюванням та інноваційним розвитком в Азербайджані. Для реалізації практичної частини дослідження використанано метод моделювання структурних рівнянь (SEM). Аналіз панельних даних здійснено за допомогою статистичного пакету PATH у програмному забезпеченні STATISTICA. За результатами проведеного дослідження не виявлено суттєвого прямого впливу змін у нормативних показниках банківської системи та відношенні валютних позик до загальної суми позик на позицію Азербайджану в Глобальному інноваційному індексі та обсяги експорту високотехнологічної продукції. Результати дослідження дають підстави стверджувати, що державні регуляторні та наглядові втручання у банківській сфрері змінюють поведінку фінансових установ та ринків, сприяючи створенню більш розвиненої та надійної фрінансової системи з точки зору ії доступності, глибини та ефективності. При цьому встановлено, що розвиток фрінансових установ та ринків сприяє інноваційному розвитку країни. Отримані результати дають підстави стверджувати, що зменшення або ліквідація державного впливу на діяльність фінансових установ та ринків призводить до посилення системного ризику та дестабілізації фрінансової системи. Таким чином, це перешкоджає розвитку інноваційного потенціалу.

Ключові слова: банківське регулювання та нагляд, Глобальний інноваційний індекс, експорт високих технологій, розвиток фінансових установ, розвиток фінансових ринків.

Manuscript received: 08.06.2020

(C) The author(s) 2020. This article is published with open access at Sumy State University 